\title{
OCCURRENCE OF SENECIO ERUCIFOLIUS L. (ASTERACEAE) IN THE WESTERN POMERANIA (NW POLAND)
}

\author{
Marek Podsiedlik, Leszek Bednorz \\ M. Podsiedlik, L. Bednorz, Department of Botany, Poznań University of Life Sciences, Wojska Polskiego 71 \\ C, 60-625 Poznań, Poland, e-mail: adeno2@op.pl, lbednorz@up.poznan.pl
}

(Received: November 17, 2015. Accepted: December 17, 2015)

\begin{abstract}
Hoary ragwort Senecio erucifolius L. (Asteraceae) is a perennial herb with Eurasiatic distribution. The species occurs rarely in most of Poland, with centre of distribution in its SE part. The paper presents the distribution and conditions of occurrence of Senecio erucifolius in the Western Pomerania (NW Poland) with reference to intraspecific taxa. Eight localities of the species were listed and described: three presently existing localities (four populations), two localities not confirmed at present and three incorrect localities. All presently existing populations of Senecio erucifolius represent subsp. erucifolius. The populations are rather small and they are the components of three plant communities: community with Calamagrostis epigejos, association Arrhenathereteum elatioris and association Tanaceto-Artemisietum. Hoary ragwort should be recognised as an endangered species of the Western Pomerania.
\end{abstract}

KeY WORDs: Senecio erucifolius, regional distribution, endangered species, Western Pomerania, Poland

\section{INTRODUCTION}

Senecio erucifolius L. (hoary ragwort) is a species of wide distribution. The general range of this species extends over a large part of Europe except from the northern part of Scandinavia, the Iberian Peninsula and south-eastern part of Europe, as well as Western and Central Asia. Its range extends in a belt through Siberia and reaches up to Yakutia (CHATER \&WALTERS 1976, Hulten \& Fries 1986, Meusel \& JäGer 1992).

Senecio erucifolius is morphologically a highly variable species. In European floras, two subspecies are most commonly distinguished within this species: subsp. erucifolius and subsp. tenuifolius Schübl. \& Martens (Chater \& Walters 1976), while less frequently five varieties: var. erucifolius, var. communis, var. tenuifolius, var. latilobus, var. viridulus are considered (Sell \& Murrell 2006, Chater 2010). According to the distribution map of S. erucifolius in Europe, taken into account intraspecific differentiation of the species, only $S$. erucifolius subsp. erucifolius occurs in Poland (Greuter 2009).

Information, regarding an occurrence of S. erucifolius localities in different regions of Poland, can be found in many local floristic and phytosociological surveys as well as in the scientific herbaria. From analysis of these data it appears that $S$. erucifolius is scatterly distributed throughout the country. Most of its localities occur in south part of Poland, mainly in the foothills of Carpathians, in a belt of central-Poland uplands and submontane basins, and in Lower Silesia (FIEK 1881, BocK 1908, FIJAŁKOWSKI 1995, KRUK \& SoBIsz 2013). Hoary ragwort was noted in Poland in different habitat conditions: on sunny slopes, in gorges, in flat river and creek valleys, in forest edges, but mainly in the ruderal sites, in meadows, grasslands and brushwoods (RADOMSKI \& JASNOWSKA 1964, 1965, Misiewicz 1972, 1981, Sudnik-WójcikowSKa 1987, Ciaciura et al. 2008, Matuszkiewicz 2008, Piotrowska 2010, RatyŃsKa et al. 2010, Czyż et al. 2012, PiwowarczyK 2012a, b). The highest stands of S. erucifolius are located in Kaczawskie Foothills at 300-400 m a.s.l. (KwiatKowski 2006). Existing data about majority of S. erucifolius localities in Poland do not account for the occurrence of intraspecific taxa. The distribution map of S. erucifolius was not prepared for 'Distribution Atlas of Vascular Plants in Poland' (ZAJĄC \& ZAJĄC 2001), mainly as a result of taxonomic ambiguities. Only recently, the first map presenting the distribution of this species in Poland 
was published (KRUK \& SoBISz 2013), but unfortunately it is not completed and needs to be complemented.

The aim of the paper was to present the distribution and conditions of occurrence of S. erucifolius in the Western Pomerania.

\section{MATERIAL AND METHODS}

Information about presented localities come from literature, Polish herbaria (Herbarium of W. Szafer Institute of Botany, Polish Academy of Sciences KRAM, Herbarium of West Pomeranian University of Technology Szczecin SZCZ), Polish Vegetation Database (University of Wrocław), oral information and our own data from field studies performed in years 2010-2015. The localities listed below are situated in the units $(10 \times 10 \mathrm{~km})$ of the ATPOL grid square system (ZAJĄC 1978). Nomenclature of taxa follows WisSKIRCHEN \& HAEUPLER (1998), and nomenclature of plant communities is based on RATYŃSKA et al. (2010).

\section{RESULTS}

Below, the list and description of Senecio erucifolius localities, noted in the area of the Western Pomerania are presented.

AB15 Dziwnów near Kamień Pomorski (leg. Ganszer 1956, KRAM 257814; leg. Kowal T. 1956, KRAM 257815, incorrectly determined - confused with Senecio jacobaea). Incorrect locality.

AB24 Kołczewo, Wolin Island (leg. Mądalski J. 1951, KRAM 503692, incorrectly determined - confused with Senecio jacobaea). Incorrect locality.

AB73 Szczecin - district Skolwin, 53³0'87.1"N, $14^{\circ} 36^{\prime} 22.4^{\prime \prime}$ E, $58 \mathrm{~m}$ a.s.l. Fields and fallow lands on the hills of Skolwin and Stołczyn (ĆwIKLIŃSKI 1970). Meadow with single hawthorns and roses, on the slope of the hill of hilltop of Odra Valley, exposure $\mathrm{SE}$, inclination $5^{\circ}, \mathrm{S}$ from the gorge in extension of Karpacka street; several dozens of clumps, area 0.5 ha; in patches of association Arrhenathereteum elatioris. Presently existing locality, S. erucifolius subsp. erucifolius occurs here; Szczecin - district Stołczyn, $53^{\circ} 30^{\prime} 14.5^{\prime \prime} \mathrm{N}, 14^{\circ} 36^{\prime} 51.1^{\prime \prime} \mathrm{E}, 3 \mathrm{~m}$ a.s.l. Hoary ragwort grows here at Stołczyńska street in the belt of nitrophilous herbal thickets, in patches of association Tanaceto-Artemisietum, between pavement and clumps of trees, near vast construction site; several dozens of clumps and single shoots in the area of 0.25 ha. The locality is endangered because of progressive leveling of the grounds and rebuilding the road. The species was reported from Szczecin by MülLER (1911) and leg. Cukiernik I. 2004 (SZCZ, incorrectly determined - confused with Senecio jacobaea) as well as with incorrect location of ATPOL unit AB9323 (leg. Ziomek M. 1999, SZCZ, incorrectly determined - confused with Senecio jacobaea). Presently existing locality, $S$. erucifolius subsp. erucifolius occurs here.

AB83 Ustowo, termophilous grasslands on the western bank of Lower Odra Valley (RADOMSKI \& JASNOWSKA 1964, 1965). Locality not confirmed at present.

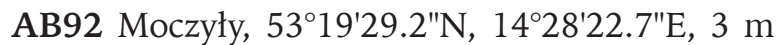
a.s.l. Not often noted in termophilus grasslands and thickets (RADOMSKI \& JASNOWSKA 1965, ZająC et al. 1993, Polish Vegetation Database). The station is located in the meadow in Odra Valley, on its eastern slope, inclination $15^{\circ}$, E from the village. About 30 clumps of hoary ragwort grow here on the area of 0.25 ha in plant community with Calamagrostis epigejos. Presently existing locality, S. erucifolius subsp. erucifolius occurs here.

From the same ATPOL square the species was reported in village Waliszewo - not existing at present - near western edge of Odra, south from the road Podjuchy-Kołbaskowo (RADOMSKI \& JASNOwSKA 1965, ZAJĄC et al. 1993). Also in this ATPOL unit - Czarna Chata, west bank of Odra (ZAJĄC et al. 1993); Kamieniec, east bank of Odra, exposure SE, inclination $15-25^{\circ}$, in grasslands and thickets (RADOMSKI \& JASNOWSKA 1964, 1965, ZAJĄC et al. 1993).

AC32 Brwice. Reported in the phytosociological relevé by PiotrowsKa (2010), from the scarp near former railway station (railway line is closed at present). Dry grassland in the flat, open space, between field road and railway tracks, on the soil build of sand and clay. Locality not confirmed at present.

AC52 Kłosów 5244'14.1"N, 14²7'44"E, $35 \mathrm{~m}$ a.s.l. Fallow land on the hilltop of Odra Valley, exposure SW, inclination $5^{\circ}$, E from the road from Kłosów towards SW, several dozens of clumps in the area of 0.25 ha in plant community with Calamagrostis epigejos. Presently existing locality, S. erucifolius subsp. erucifolius occurs here.

BB01 Miechęcino near Kołobrzeg (leg. Mądalski J. 1947, KRAM 503694, incorrectly determined - confused with Senecio jacobaea). Incorrect locality.

\section{DISCUSSION}

Totally, eight localities of Senecio erucifolius were reported in the Western Pomerania: three presently existing localities (including four populations), two localities not confirmed at present and three incorrect localities (Fig. 1). The last ones came from herbaria materials. After their revision it appeared that they were incorrectly determined - hoary ragwort were confused with morphologically similar and closely related species Senecio jacobaea. The map presenting the distribution of S. erucifolius in Poland prepared by KRUK \& SoBIsz (2013) should be therefore complemented with localities given above.

Morphological analysis of collected specimens of S. erucifolius revealed that all presently existing pop- 


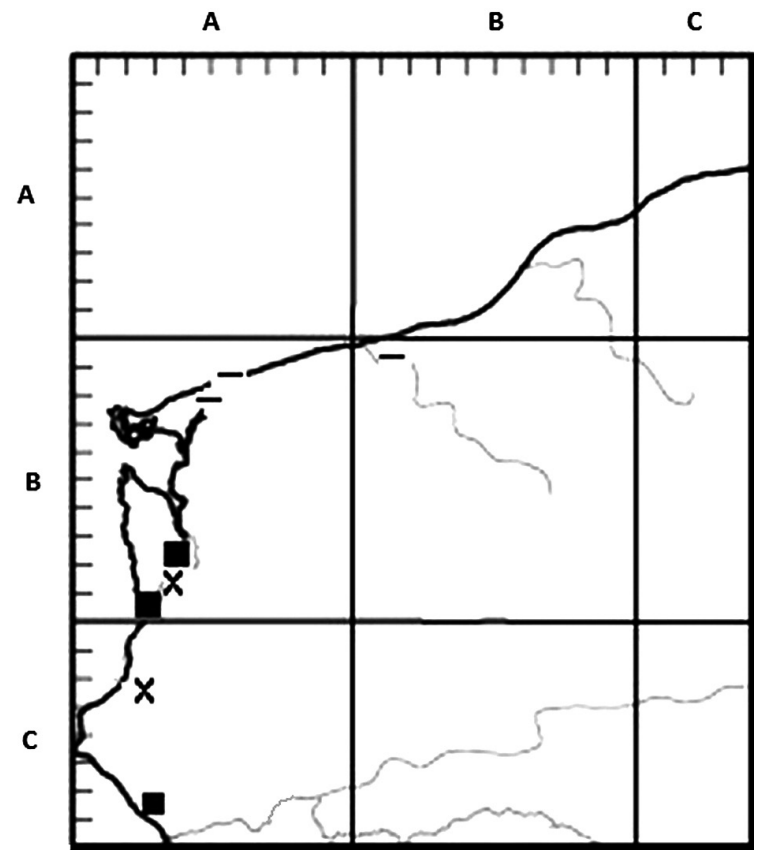

Fig. 1. Distribution of Senecio erucifolius in the Western Pomerania: - presently existing locality, $\times$ - locality not confirmed at present, - - incorrect locality

ulations of the species in the Western Pomerania represent subsp. erucifolius, which is considered as atlantic taxon (Soó 1970). Also in the neighbouring Mecklenburg-Vorpommern the same subspecies occurs (FuKAREK \& HenKer 2006).

Inventoried populations of hoary ragwort occupy the stands located in the valley of Lower Odra and adjacent areas lying at 3-58 $\mathrm{m}$ a.s.l. The stations are located on the slopes with eastern and south-eastern exposure except one locality on flat terrain. The populations occupy the area $0.25-0.5 \mathrm{ha}$, and their numbers amount to several dozens of clumps. In Moczyły and Kłosów hoary ragwort occur in plant community with Calamagrostis epigejos, and in Szczecin in the patches of associations Arrhenathereteum elatioris and Tanaceto-Artemisietum.

Senecio erucifolius was put earlier in the red list of endangered species of the Western Pomerania as a species of undefined threat, because of lack of sufficient information (ŻUKOWSKI \& JACKOWIAK 1995). Taking into consideration the observed recently processes of intensification of agriculture and related to it elimination of fallow lands, spread of invasive pland species such as Solidago gigantea and Calamagrostis epigejos, and urbanization of outskirts of the cities, threat to the species seems to be unquestionable. The materials presented in this study complement our knowledge about the present state of hoary ragwort in the Western Pomerania.

\section{ACKNOWLEDGEMENTS}

This study was supported by the Ministry of Science and Higher Education which provided funding for young scientists activities under grant no. 507.641. We would like to thank prof. dr hab. Janina Borysiak, dr hab. Mariola Wróbel, dr Monika Myśliwy and dr Edyta Stępień for sharing their materials and information and also dr hab. Zygmunt Kącki (Polish Vegetation Database) for making the database available.

\section{REFERENCES}

Bоск W. (1908): Taschenflora von Bromberg (Das Netzegebiet). Mittler'sche Buchhandlung (A. Fromm Nachf.), Bromberg.

Chater A.O. (2010): Flora of Cardiganshire. Chater A.O., Aberystwyth.

Chater A.O., Walters S.M. (1976): Senecio L. In: T.G. Tutin, V.H. Heywood, N.A. Burges, D.M. Moore, D.H. Valentine, S.M. Walters, D.A. Webb (eds). Flora Europaea 4. Plantaginaceae to Compositae (and Rubiaceae). Cambridge University Press, Cambridge: 19-205.

Ciaciura M., Pasicka I., Więctaw H. (2008): Zagrożone i rzadkie gatunki roślin naczyniowych w gminie Lubsko. Zeszyty Naukowe Uniwersytetu Szczecińskiego, Acta Biologica 503(14): 4-52.

Czyż H., Kitczak T., Sarnowski A. (2012): Walory florystyczne, użytkowe i przyrodnicze użytków zielonych na tarasie zalewowym doliny Warty. Rocznik Ochrona Środowiska 14: 329-336.

ĆwiKLIŃski E. (1970): Flora synantropijna Szczecina. Monographiae Botanicae 33: 1-103.

FieK E. (1881): Flora von Schlesien preussischen und österreichischen Antheils, enthaltend die wildwachsenden, verwilderten und angebauten Phanerogamen und Gefass-Cryptogamen. J.U. Kern's Verlag, Breslau.

FiJAŁKOWSKi D. (1995): Flora roślin naczyniowych Lubelszczyzny. Lubelskie Towarzystwo Naukowe, Lublin.

Fukarek F., Henker H. (2006): Flora von Mecklenburg-Vorpommern, Farn- und Blütenpflanzen. Weissdorn-Verlag, Jena.

Greuter W. (2009): Compositae (pro parte majore). In: W. Greuter, E. von Raab-Straube (eds). E Euro + Med Plantbase - the information resource for Euro-Mediterranean plant diversity. Dostępny w Internecie: ww2.bgbm.org/EuroPlusMed [access: 11.2015].

Hulten E., Fries M. (1986): Atlas of north European vascular plants-north of the tropic cancer. Vol. 2. Koeltz Scientific Books, Königstein.

KRUK K., SobISZ Z. (2013): Occurrence and distribution of Senecio erucifolius L. (Asteraceae) in Poland. Thaiszia Journal of Botany 23(1): 1-8.

KwiATKOWski P. (2006): Current state, separateness and dynamics of vascular flora of the Góry Kaczawskie (Kaczawa Mountains) and Pogórze Kaczawskie (Kaczawa Plateau). I. Distribution at- 
las of vascular plants. W. Szafer Institute of Botany, Polish Academy of Sciences, Kraków.

Matuszkiewicz W. (2008): Przewodnik do oznaczania zbiorowisk roślinnych Polski. Wyd. Nauk. PWN, Warszawa.

Meusel H., JÄGER E.J. (1992): Vergleichende Chorologie der Zentraleuropäischen Flora. Bd. 3. Gustav Fischer Verlag, Jena.

Misiewicz J. (1972): Niektóre aspekty synantropizacji flory i zbiorowisk roślinnych projektowanego rezerwatu stepowego w rejonie Gorzów-Wieprzyce. Phytocoenosis 1(4): 283-286.

MisIewicz J. (1981): Badania nad florą synantropijną Gorzowa Wielkopolskiego. WSP w Słupsku, Słupsk.

MülLER W. (1911): Flora von Pommern. J. Burmeister's Buchhandlung, Stettin.

PiotrowsKa J. (2010): Ocena stanu zachowania wybranych populacji goryczki krzyżowej (Gentiana cruciata) na Pomorzu Zachodnim. Folia Pomeranae Universitatis Technologiae Stetinensis. Agricultura, Alimentaria, Piscaria et Zootechnica 278(14): 57-74.

PIWOWARCZYK R. (2012a): A revision of distribution and the ecological description of Orobanche picridis (Orobanchaceae) at the NE limit of its geographical range from Poland and Ukraine. Acta Agrobotanica 65(1): 91-106.

PiWOWARCZYK R. (2012b): Orobanche alba subsp. alba and subsp. major (Orobanchaceae) in Poland: current distribution, taxonomy, plant communities, hosts and seed micromorphology. Biodiversity Research and Conservation 26: 32-37.

RADOMSKI J., JASNOWSKA J. (1964): Roślinność otwartych zbiorowisk na zachodniej krawędzi doliny dolnej Odry. Zeszyty Naukowe WSR w Szczecinie, Rolnictwo 17: 86-106.

RADOMSKI J., JASNOWSKA J. (1965): Roślinność zbiorowisk murawowych na zachodniej krawędzi doliny dolnej Odry. Zeszyty Naukowe WSR w Szczecinie, Rolnictwo 19: 69-83.
Ratyńska H., Wojterska M., Brzeg A., Kołacz M. (2010): Multimedialna encyklopedia zbiorowisk roślinnych Polski ver. 1.1. Uniwersytet Kazimierza Wielkiego w Bydgoszczy, Instytut Edukacji Technicznej i Informatycznej Bydgoszcz-Poznań-Warszawa.

Sell P.D., Murrell G. (2006): Senecio. In: Flora of Great Britain and Ireland. Vol. 4. Asteraceae. Cambridge University Press, Cambridge: 488-503.

Soó R. (1970): A Magyar Flóra és vegetáció rendszertani növényföldrajzi kézikönyve. Akadémiai Kiadó, Budapest.

SUDNIK-WÓJcIKOWSKA B. (1987): Flora miasta Warszawy i jej przemiany w ciągu XIX i XX wieku. T. 1, 2. Wyd. UW, Warszawa.

Wisskirchen R., Haeupler H. (1998): Standardliste der Farn-und Blutenpflanzen Deutschlands. Ulmer, Stuttgart.

ZająC A. (1978): Założenia metodyczne „Atlasu rozmieszczenia roślin naczyniowych w Polsce". Wiadomości Botaniczne 22(3): 145-155.

Zając A., Ciaciura M., Zając M. (1993): Rośliny naczyniowe Zaodrza (na zachód od Szczecina). Uniwersytet Szczeciński. Rozprawy i Studia 142: $1-151$.

ZająC A., ZająC M. (eds) (2001): Atlas rozmieszczenia roślin naczyniowych w Polsce. Pracownia Chorologii Komputerowej Instytutu Botaniki Uniwersytetu Jagiellońskiego i Fundacja dla Uniwersytetu Jagiellońskiego, Kraków.

ŻUKowsKi W., JACKowiak B. (1995): Lista roślin naczyniowych ginących i zagrożonych na Pomorzu Zachodnim i w Wielkopolsce. In: W. Żukowski, B. Jackowiak (eds). Ginące i zagrożone rośliny naczyniowe Pomorza Zachodniego i Wielkopolski. Bogucki Wyd. Nauk., Poznań. Prace Zakładu Taksonomii Roślin UAM w Poznaniu 3: 6-96.

For citation: Podsiedlik M., Bednorz L. (2016): Occurrence of Senecio erucifolius L. (Asteraceae) in the Western Pomerania (NW Poland). Steciana 20(1): 3-6. doi: 10.12657/steciana.020.001 